\title{
TRICHOPTERA FROM THE MOUNTAINS OF NORTH CAROLINA AND TENNESSEE
}

\author{
By F. M. CARPENTER \\ Museum of Comparative Zoology
}

The caddis-flies listed in this paper were collected by Professor Nathan Banks, Dr. P. J. Darlington, Jr., and the writer in the Black Mountains of North Carolina and the Smoky Mountains of North Carolina and Tennessee during August and September of 1930. Several specimens collected by Dr. and Mrs. W. S. Creighton in the Black Mountains at about the same time are also included. For the opportunity of studying this material and for many helpful suggestions, I am indebted to Professor Banks. The types of all new species are deposited in the Museum of Comparative Zoology.

The summer of 1930 was very dry in the southern Appalachian region and as a consequence caddis-flies were not very abundant. But about two hundred and fifty specimens were collected, belonging to twenty-three species, including five new ones, as well as three new genera. Several species previously known only from the types were taken in considerable numbers, and both sexes of other species formerly known only by one sex were also secured.

\section{LIMNEPHILIDE}

Neophylax mitchelli n. sp.

Text-figure 1

${ }_{0}$ Length of fore wing, $7 \mathrm{~mm}$. Vertex and frons yellow; antennæ light yellow; hairs on head and antennæ goldenyellow; maxillary palpi yellow; basal segments of maxillary palpi not much thicker than the other segments; thorax 
light reddish brown; abdomen dark reddish brown above, light brown laterally and ventrally; legs light brown. Fore wing: yellowish, with areas of gray or shading; one large light yellow spot on the posterior border; outer margin bordered with gray, the center of the wing more or less maculate; venation as in other members of this genus, Rs forking close to its origin. Hind wing: M reduced as in all other males of Neophylax; $\mathrm{M} 3^{+} 4$ is in actual contact with
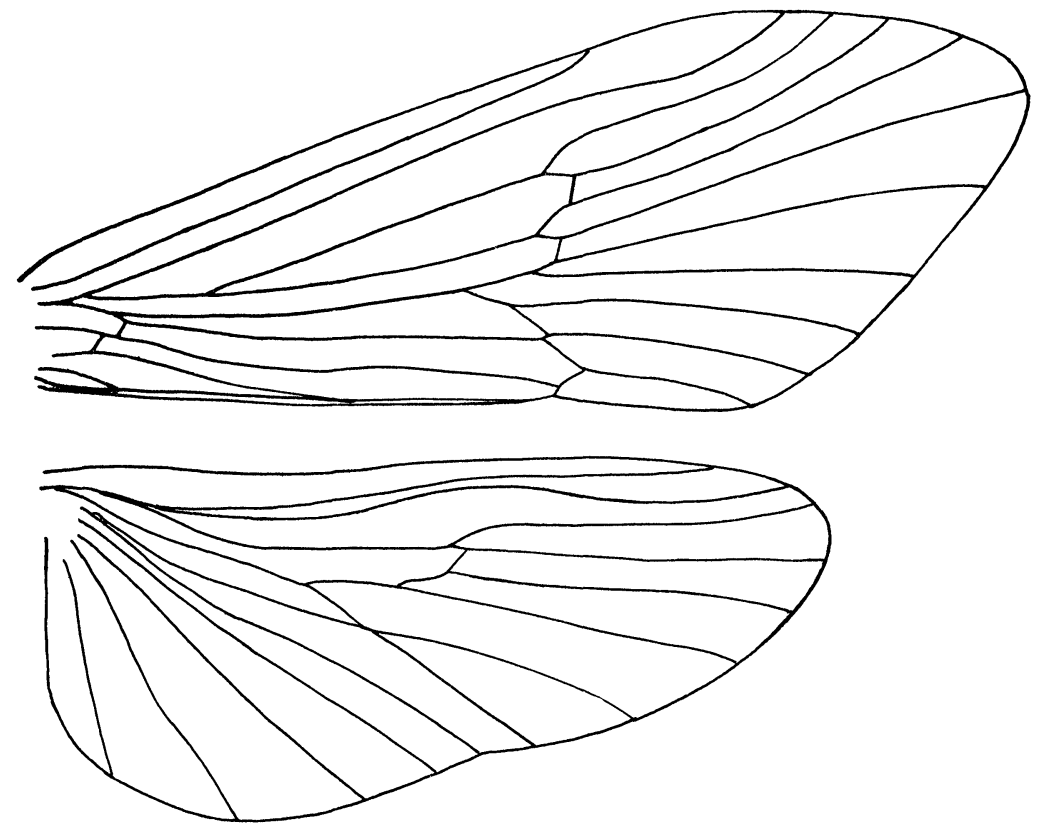

Fig. 1. Venation of Neopbylax mitchelli, n. sp.

$\mathrm{Cu} 1$ for a short distance; $\mathrm{M}$ is free from $\mathrm{Rs}$ for its entire length, arising independently from the base of the wing. The hind wing is uniformly light yellow.

Holotype ( $\delta$ ) : Mt. Mitchell, Black Mountains, N. Carolina, at 5000-6711 ft., Sept. 1, 1930; N. Banks, collector.

This species differs from the previously described members of Neophylax by its color markings and particularly by the free basal part of $\mathrm{M}$ in the hind wing. In all other 
American species of Neophylax the stem of M fuses with Rs just a little basad of the fork of M. The condition in mitchelli is quite unique and probably should rank as a subgeneric division. The spur formula of the type is $1,2,3$ instead of 1, 2, 4 as usual in the genus. This in all probability is also a subgeneric characteristic, but additional specimens may show that it is only an individual feature and subject to variation.

\section{Allegophylax subfasciatus Say}

This common eastern species was taken at three localities: Deep Creek, Bryson City, N. Carolina, 2000 ft., Aug. 20, 27 ; Newfound Gap, Smoky Mts., Tennessee, 5000-5200 ft., Sept. 1; and on the state road to Newfound Gap, Tennessee, at $3500 \mathrm{ft}$. , Sept. 3.

\section{SERICOSTOMATIDE}

\section{Notiopsyche Banks}

Banks, 1905, Bull. Amer. Mus. Nat. Hist., 21 :216.

Banks, 1905, Trans. Amer. Ent. Soc., 32:11.

o Spurs 2, 4, 4; ocelli absent; maxillary palpi short and flattened, covered with scales; labial palpi long and slender; basal segment of antennæ longer than head and covered with scales and stout hairs. Fore wing: costal area of wing rather broad, the margin slightly recurved and bearing a series of long hairs, some of which extend backwards to about the middle of the wing; all four branches of Rs present; $\mathrm{M}$ with three branches, M1, M2, and M3+4; Cu1 unbranched. Hind wing; costal margin slightly recurved and bearing short recurved hairs; Rs with four branches, M with only two; Cu1 forked.

o Similar to the male, except for the following: the maxillary palpi are 5-segmented and normal in shape; basal segment of antennæ long, bearing long hairs, but no scales; the anterior margin of the fore wing is normal and lacks the long, recurved hairs.

Genotype: Notiopsyche latipennis Banks. 
Banks originally established this genus for latipennis, and later (1911) placed another species here (carolina). Latipennis has previously been known only by the male type, but in the new material obtained in 1930, there are fifteen more specimens belonging to both sexes, which have enabled me to prepare a more complete description of the male and to describe the female for the first time. Carolina is known only by the three male types, all from Southern Pines, North Carolina, there being no additional specimens from the mountainous regions of that state. From my examination of these types, which are in the Museum of Comparative Zoology, I am convinced that carolina does not belong to Notiopsyche, but to an undescribed, aberrant genus, which I propose to call Oligopsyche. The characteristics of that genus will be considered below.

\section{Notiopsyche latipennis Banks}

Figure 14.

1905, Bull. Amer. Mus. Nat. Hist. 21; 216.

1905, Trans. Amer. Ent. Soc. 32: 11; pl. 2, fig. 20 (forewing), fig. 27 ( o genitalia).

o Length of fore wing, $8 \mathrm{~mm}$. Face grayish brown; antennæ mostly yellow-brown, the distal edge of each segment dark brown; basal segment dark brown and covered with brown scales and hairs; maxillary palpi movable, bearing yellow scales in the upper surface and dark brown hair and slender scales below; legs and thorax yellowish brown; wings uniformly gray; the anterior margin bearing long yellow hairs, some of which extend backward as far as the middle of the wing; veins and some membraneous areas of the wings bear flat, scale-like hairs. Forewing ${ }^{1}$ : fork $\mathrm{R} 4{ }^{+} \mathbf{5}$ deeper than $\mathrm{R}^{+} 3$; $\mathrm{M}^{+} 2$ divide below the separation of $\mathrm{R} 4^{+} 5$. The male genitalia have been figured by Banks.

o Similar to the male in size, coloration and venation, ex-

1The figure of the wing of this insect given by Banks (1905) is not quite correct, and the figure of both fore and hind wing published by Ulmer in the Genera Insectorum (pl. 13, fig. 114) is likewise incorrect. Ulmer accidently labels this wing Notiopsyche mexicana. 
clusive of the secondary sexual characters mentioned in the generic description.

Holotype ( $\hat{o}$ ) : Black Mt., North Carolina, June; in the Museum of Comparative Zoology.

Allotype, by present designation: Bryson City, Deep Creek, North Carolina, 2000 ft., Aug. 25, 1930; N. Banks, collector.

In addition to the allotype, 11 specimens were collected in 1930: 9 at Bryson City, North Carolina, from Aug. 2527; 1 at Smokemont, North Carolina, 2000 ft., Aug. 24; and 1 at Newfound Gap, Smoky Mts., Tennessee, 5000-5200 ft., Sept. 1.

\section{Oligopsyche, new genus}

o Spurs, 2, 4, 4; ocelli absent; mouth-parts vestigial, the maxillary palpi reduced to a pair of small papillæ bearing a few short hairs; mandibles and labrum completely absent; labial palpi short, with 3 segments; basal segment of antennæ slender, long, and very hairy; fore wings broad, and bearing a prominent fringe of light yellow hairs; Rs arising close to base of wing; $M$ fused with $\mathrm{Rs}_{\mathrm{s}}$ at the base; $\mathrm{Rs}_{\mathrm{s}}$ and $\mathrm{M}$ with two branches each; $\mathrm{Cu}$ unbranched. Female unknown.

Genotype: Notiopsyche carolina Banks. The genitalia have been figured by Banks (1911).

The species for which this genus is established is one of the most unusual in the family Sericostomatidæ. One of the outstanding features of the members of the family is the elaboration of the maxillary palpi of the male, which are usually enlarged. In carolina, the opposite condition has been developed; the palpi are almost entirely lost. This reduction of the palpi is probably a part of the much greater modification, the atrophy of all the mouth-parts. The venation is also much more reduced than is usual in the Sericostomatids.

\section{Phanopsyche grisea Banks}

Trans. Amer. Ent. Soc., 1911, 37: 357; fig. 17 (wing), fig. 22 (genitalia). 
Four specimens of this species were collected at Newfound Gap, 5000-5200 ft., Smoky Mts., Tennessee; Aug. 30, 31 ; one at Bryson City, Deep Creek, 2000 ft., North Carolina, Aug. 26 ; and 1 at Nantahala Gorge, North Carolina, August 25. This series of specimens greatly extends the range of grisea, which has previously been recorded only from New York and New Jersey.

\section{Goera calcarata Banks}

Figures 8, 13.

Trans. Amer. Ent. Soc. 25: 211, 1899.

One female of this species was collected at Andrews, North Carolina, 1800 ft., Aug. 25. Calcarata was originally described from a single female from Sea Cliff, New York, and is represented in the collections at the Museum of Comparative Zoology by several additional specimens from New Jersey, Massachusetts, and New York. Since the male has not previously been described, I take this opportunity to do so.

o Spurs 2, 4, 4. Head dark reddish brown; basal segment of antennæ thickened and a little longer than the head hairy, and slightly scaly; palpi light brown, cylindrical, fleshy, almost hairless, except at top, where there is a cluster of long, light yellow hairs; thorax reddish brown; legs yellow. The venation, which is shown in figure 13, is the same as in the female. The male genitalia are illustrated in figure 8.

Allotype, by present designation: Ramsey, New Jersey, July 27, 1917; in Museum of Comparative Zoology.

\section{Pseudogoera, new genus (Gocrinæ)}

ô Spurs 2, 4, 4; ocelli absent, maxillary palpi slender, cylindrical, covered with long hairs; basal segment of antennæ thickened, but not so long as the head. Fore wing: $\mathrm{R} 1$ connected to R2 by an oblique cross-vein below the pterostigmal region; Rs with two branches, $\mathrm{M}$ with four; $\mathrm{Cu} 1$ unbranched.

Genotype: Pseudogoera singularis, n. sp. 
Pseudogoera singularis, n. sp.

Figures 2, 12.

o Length of fore wing, 6-7 mm.; vertex and frons dark brown; antennæ light brown, the basal segment covered with long, dark brown hairs; maxillary palpi grayish, with long dark gray hairs, those at the base being the longest; labial palpi long, gray; thorax light brown, abdomen dark reddish brown; legs light brown, with darker hairs. Fore wing: broadest beyond middle of wing; $\mathrm{Rs}$ arising close to the base; $\mathrm{M}$ dividing into $\mathrm{M} 1+2$ and $\mathrm{M} 3+4$ below the division of $\mathrm{Rs}$; $\mathrm{R}^{*} 5$ separating before $\mathrm{R} 2+3$; $\mathrm{Cu} 2$ and anal veins apparently absent, although there is a short vein leading from the hind margin and terminating on $\mathrm{Cu} 1$ near its distal end; this is probably a remnant of an anal vein which was originally more or less marginal. Hind wing: cross-vein between R1 and R2+3 missing. All four branches of $\mathrm{RS}$ present; M with two branches; Cu1 forked. Genitalia as in figure 2 .

Female unknown.

Holotype ( $\hat{o}$ ), Bryson City, Deep Creek, 2000 ft., North Carolina, Aug. 26, 1932, N. Banks, collector; in Museum of Comparative Zoology.

Paratype: 1 ô, same locality and date as holotype; in $\mathrm{Mu}-$ seum of Comparative Zoology.

So far as the tibial spurs are concerned, this species belongs to the subfamily Goerinæ; but it is separated from all other genera of that group by the possession of the vein between R1 and R2 below the pterostigma. In fact, the only other North American genus of the Sericostomatidæ in which this vein is present is Agarodes, which has only two spurs on the middle tibiæ and which is therefore a member of the Sericostomatinæ.

Neuropsyche, new genus (Lepidostominæ)

ô Spurs, 1, 4, 4; ocelli absent; maxillary palpi short, slightly flattened, covered with long gray hairs and scales, basal segment of antennæ thickened, but not so long on the 
head. Fore wing: Rs arising close to the base, with three branches (R2, R3, R4+5) ; M with two branches; $\mathrm{Cu} 1$ unbranched.

o Spurs 1, 4, 4; basal segment of antennæ longer than that of male and less thickened; venation similar to that of male, except that $\mathrm{R} 4^{+} 5$ is forked in both fore and hind wings.

Genotype: Neuropsyche tibialis, n. sp.

Neuropsyche tibialis, n. sp.

Figures 3, 15, 16.

ô Length of fore wing, 6-7 mm; vertex and frons light yellow; antennæ light yellow; the basal segment covered with light yellow hairs; maxillary palpi yellow, the ventral surface covered with long, brown hairs, and the dorsal surface, with whitish scales; labial palpi short, gray; thorax, legs, and abdomen light yellow. Fore wing: rather slender, nearly oval; $\mathrm{R}^{+}+5$ arising before the middle of wing; $\mathrm{M}$ dividing just beyond mid-wing. Hind wing: Rs branched as in fore wing; M with two branches, arising before origin of $\mathrm{R}^{+} 5$; $\mathrm{Cu} 1$ unbranched. The wings are covered with flattened yellow hairs.

o Color and size as in male.

Holotype ( $\hat{o}$ ) and allotype: Bryson City, Deep Creek, North Carolina, Aug. 27, 1930 ; P. J. Darlington, collector.

Paratypes: 1 o Bryson City, North Carolina, Aug. 23; 7 oे ô, Bryson City, Aug. 26; 3 oे ôे, Bryson City, Aug. 27; 2 ㅇ , Bryson City, Aug. 23; 3 ㅇ , Bryson City, Aug. 26; 1 \%, Nantahala Gorge, North Carolina, Aug. 25, 1930. All types in Museum of Comparative Zoology.

Neuropsyche is readily distinguished from the other North American genera of Sericostomatidæ by the possession of one tibial spur on the front legs, and four on the middle ones. This condition is not present in any other genera of our fauna, except the very aberrant Nosopus. I have placed the genus tentatively in the Lepidostominæ, but its position is not at all certain. 


\section{Micrasema falcata Banks}

Nine specimens were taken at Deep Creek, Bryson City, Smoky Mts., Aug. 26 and 27; Smokemont, Smoky Mts., N. Carolina, Aug. 24; and Andrews, N. Carolina, Aug. 23.

\section{RHYACOPHILIDE}

\section{Rhyacophila fuscula Walker}

Figure 5 .

Ten specimens of this species were collected at the following localities: Newfound Gap, Smoky Mts., 5000-5200 ft., Tennessee, Sept. 1; Smokemont, N. Carolina, Aug. 24; Bryson City, N. Carolina, Aug. 23-27; Nantahala Gorge, $2000 \mathrm{ft}$., N. Carolina, Aug. 25. This is the first record of the species south of New Jersey known to me.

\section{Rhyacophila torva Hagen}

Figure 7.

Rhyacophila torva Hagen, 1861, Syn. Neur. N. A., 296.

Rhyacophila terminata Banks, Proc. Ent. Soc. Wash., 8: 132 ; fig. 7.

Over forty specimens of this species were collected at Nantahala Gorge, Bryson City and Smokemont, N. Carolina; and other specimens were taken between Blowing Rock and Linville, N. Carolina; Willets, N. Carolina; Andrews, N. Carolina; and Newfound Gap, Smoky Mts., Tennessee. This is perhaps the commonest of our eastern species of Rhyacophila. As I have indicated above, Banks' terminata is synonymous with torva; the types of both of these species, now in the Museum of Comparative Zoology, are identical. Betten has suggested ${ }^{2}$ that the species which Banks identified and figured as torva is the same as nigrita Banks; but I am not sure that this is so, since I cannot locate the specimen on which Banks based his figure. For purposes

2List of the Insects of New York, p. 522, 1926. 
of comparison I have included here a drawing of the genitalia of nigrita, which was originally described from the Black Mountains, N. Carolina (figure 11.)

\section{Rhyacophila glaberrima Ulmer}

Ulmer, 1907, Coll. Selys, 6, Trichoptera: 85 ; fig. 131, 132.

This species has previously been known only by the male type, collected many years ago in Georgia ${ }^{3}$. I therefore take this opportunity to describe the female, several specimens of which were collected in 1930 :

$q$ Color of body similar to that of $\hat{s}$, the head except frons dark brown; frons yellowish; hairs on vertex, at least those between the ocelli, yellowish brown; the warts between the ocelli are very prominent and elongate-oval in shape; the posterior warts are also long and oval. The female herewith designated as allotype was collected by the writer between Blowing Rock and Linville, N. Carolina, at an altitude of 3-4000 feet, September 8, 1930.

Forty additional specimens, of both sexes, were collected at the following localities: Bryson City, N. Carolina, Aug. 26-27; Nantahala Gorge, Aug. 25; Andrews, Aug. 25 ; Mt. Mitchell, about 4000 ft., Sept. 4; Little Switzerland, Black Mountains, N. Carolina, Sept.; and Newfound Gap, Smoky Mt., 5000-5200 ft., Tenn., Sept. 1-3. The insects resemble torva superficially, but the males are easily separated by the genital structure, as can be seen by comparing Ulmer's figure of glaberrima with that of torva given here (figure 7 ). The females can be distinguished by the hairs on the vertex, which are a very dark brown in torva but light brown or even yellow in glaberrima; and by the interocellar and posterior warts, which are rounded and flattened in torva, but oval and prominent in glaberrima.

\section{Rhyacophila carolina Banks}

Two males found at Bryson City, N. Carolina, Aug. 26, and another on the road between Blowing Rock and Linville, N. Carolina, Sept. 8.

3In the Genera Insectorum (1907) Ulmer erroneously gives the type locality as Massachusetts. 
Rhyacophila montana, n. sp.

Figure 10.

Male: Length of fore wing, $5 \mathrm{~mm}$. Body uniformly dark brown, nearly black; ocelli white; wings uniformly smoky brown, probably with golden spots in fresh specimens. Fore wing: R2 ${ }^{+} 3$ and $R 4^{+} 5$ forked to the same depth; M dividing just basal of the origin of $R_{S}$; forks of $M$ shallow, fork $\mathrm{M} 1+2$ not so deep as fork $\mathrm{M} 3^{+} 4$; $\mathrm{Cu}$ forked directly below origin of Rs. Hind wing: fork M $3+4$ deeper than fork R2 ${ }^{+} 3$; $\mathrm{M} 3+4$ not forked; $\mathrm{M}$ dividing first directly below origin of Rs. Genitalia as in figure 10.

Female: Length of fore wing, $7 \mathrm{~mm}$.; similar to the male in coloration and venation. The wings have more hair than those of any of the males, and show several golden spots.

Holotype ( $\delta$ ), Newfound Gap, Smoky Mts., 5000-5200 ft., Tennessee, Aug. 30, 1930; N. Banks, collector. Allotype: same locality, Sept. 3; F. Carpenter, collector.

Paratypes: 3 males, same data as holotype, N. Banks, collector; 1 male, same locality, Aug. 31, F. Carpenter ; 1 male, Bryson City, Deep Creek, 2000 ft., Aug. 23, N. Banks.

\section{Paragapetus moestus Banks}

Three males were taken at Deep Creek, Bryson City, North Carolina, Aug. 23, and two males at Newfound Gap, Smoky Mountains, Tennessee, Aug. 30. The types of the species were collected at Black Mt., North Carolina.

\section{Glossosoma nigrior Banks}

Previously known only by the type specimens from Black Mountains, N. Carolina, this species was well represented in the 1930 collection by thirteen males and females, taken at Deep Creek, Bryson City, N. Carolina, Aug. 26, 28; and Nantahala Gorge, N. Carolina, Aug. 25.

\section{Chimarrha aterrima Hagen}

One male was collected at Andrews, N. Carolina, $1800 \mathrm{ft}$., 
Aug. 25, and another at Nantahala Gorge, N. Carolina, 2000 ft., Aug. 27.

\section{HYDROPSYCHIDE}

\section{Hydropsyche alternans Walker}

Figure 1.

Seven specimens of this common eastern species were taken at Bryson City, N. Carolina, and also at Smokemont, Andrews, and Willets, Aug. 24 and 25.

\section{Hydropsychodes minuscula Banks}

Although originally described from Plummer's Island, Maryland, this species was represented by thirteen species from Nantahala Gorge, Andrews, Ashland in N. Carolina, Aug. 22-25; and near the French Broad River, Tennessee, 6 miles west of the N. Carolina line, Aug. 28.

\section{POLYCENTROPID $Æ$}

\section{Phylocentropus carolinus, n. sp.}

Figure 9.

o Length of fore wing, $6 \mathrm{~mm}$; vertex and frons graybrown; antennæ yellow, except the basal segment, which is brown; thorax covered with bray-brown hairs; legs yellow; wings spotted with brown and yellow. Fore wing: Rs arising near the middle of the wing; forks $\mathrm{R}^{+} 3$ and $\mathrm{R}^{+} 5$ are the same depth; fork $\mathrm{M} 3{ }^{+} 4$ deeper than $\mathrm{M} 2{ }^{+} 3$; $\mathrm{M}$ dividing before the origin of $\mathrm{Rs}$; $\mathrm{Cu} 1$ forked below Rs. Genitalia as in figure 9. Female unknown.

Holotype ( $\hat{o}$ ) : Nantahala Gorge, 2000 ft., N. Carolina, Aug. 25; N. Banks, collector. Paratypes: two males, Bryson City, Deep Creek, N. Carolina, Aug. 26; N. Banks, collector; one male, Bryson City, Aug. 25, F. Carpenter, collector; four males, Nantahala Gorge, N. Carolina, Aug. 25, N. Banks, collector.

This species is the fourth to be described in the genus; it 
is closest to lucidus Hagen, but the genital appendages are much larger in carolinus than in Hagen's species.

\section{Neuroclipsis parvula Banks}

This species, originally described from Maryland, has subsequently been found in northern New York. Two specimens were collected in 1930: one male at Andrews, N. Carolina, Aug. 23; and one near the French Broad River, Tennessee, 6 miles west of the N. Carolina state line, Aug. 28.

\section{PSYCHOMIID $Æ$ \\ Psychomyia flavida Hagen}

Figure 6.

This species has been taken commonly from the District of Columbia to eastern Canada, but not previously in the southern states; two specimens were collected in Nantahala Gorge, N. Carolina, Aug. 25.

\section{PHILOPTAMIDAE}

\section{Philopotamus distinctus Walker}

Fifteen specimens were taken in the Smoky Mt. and Black Mt. region: Bryson City, Andrews, Linville, Marshall and Black Mt., all N. Carolina; and Newfound Gap, Smoky Mts., Tennessee, during late August and early September.

\section{LEPTOCERID $\#$}

\section{Mystacides nigra Linn.}

One male was taken at Andrews, N. Carolina, Aug. 25, at an altitude of about 1800 . This conspicuous insect has been recorded from most of the northern states and Canada, but I have not seen any specimens previously collected south of the District of Columbia and vicinity. It is interesting that no specimens were secured in the Black Mts. or Smoky 
Mts. proper, where one would expect to find such a northern species.

\section{Plate I.}

Male genitalia, lateral views.

Figure 1. Hydropsyche alternans Walker

Figure 2. Pseudogoera singularis, n. sp.

Figure 3. Neuropsyche tibialis, n. sp.

Figure 4. Paragapetus moestus Banks

Figure 5. Rhyacophila fuscula Walker

Figure 6. Psychomyia flavida Hagen

Figure 7. Rhyacophila torva Hagen

Figure 8. Goera calcarata Banks

Figure 9. Phylocentropus carolinus, n. sp.

Figure 10. Rhyacophila montana, n. sp.

Figure 11. Rhyacophila nigrita Banks

\section{Plate II.}

Figure 12. Pseudogoera singularis, n. sp., fore wing.

Figure 13. Goera calcarata Banks, fore wing.

Figure 14. Notiopsyche latipennis Banks, fore wing.

Figure 15. Neuropsyche tibialis, n. sp., fore wing.

Figure 16. Neuropsyche tibialis, n. sp., hind wing.

Figure 17. Phanopsyche grisea Banks, fore wing. 


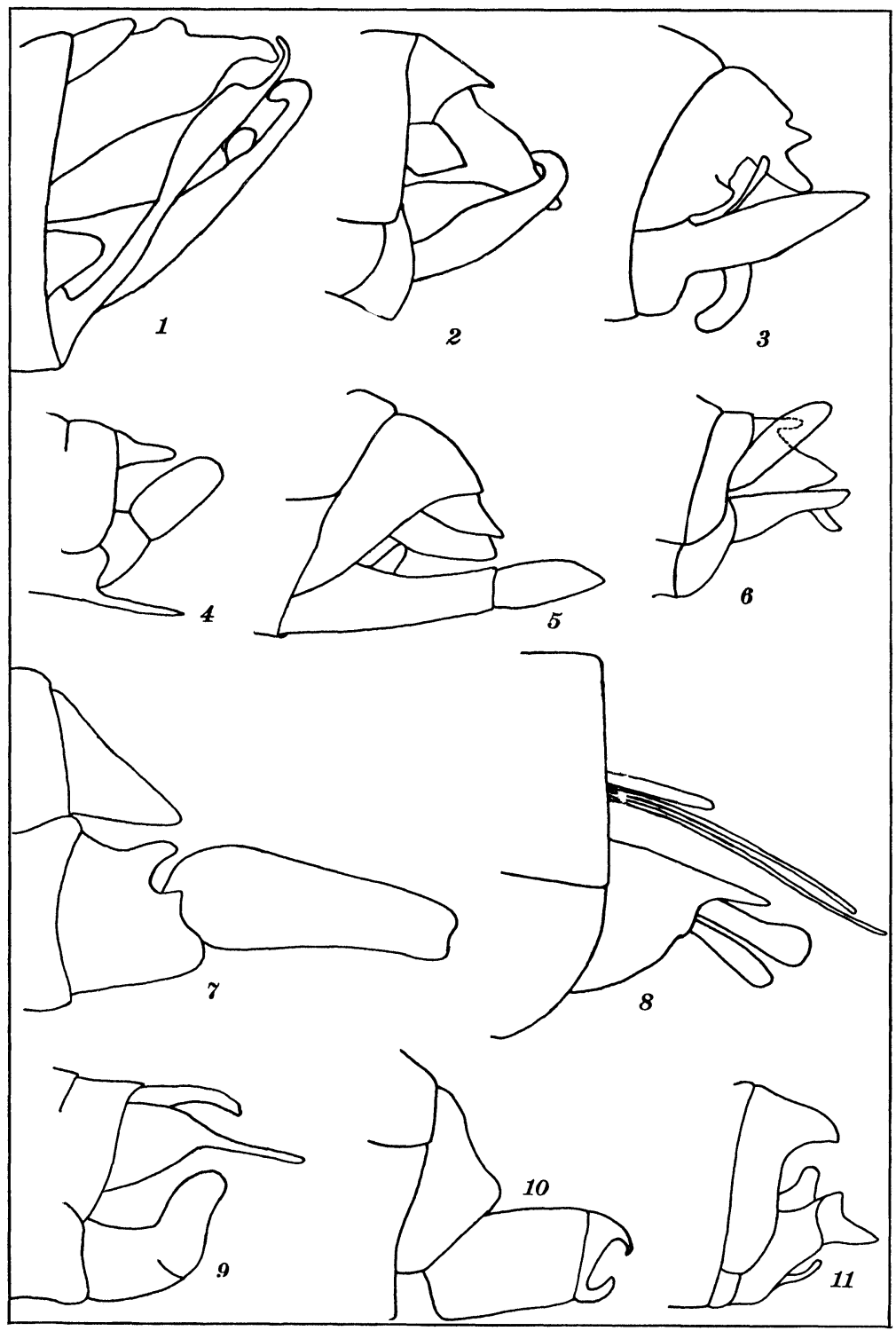

Carpenter-Trichoptera 


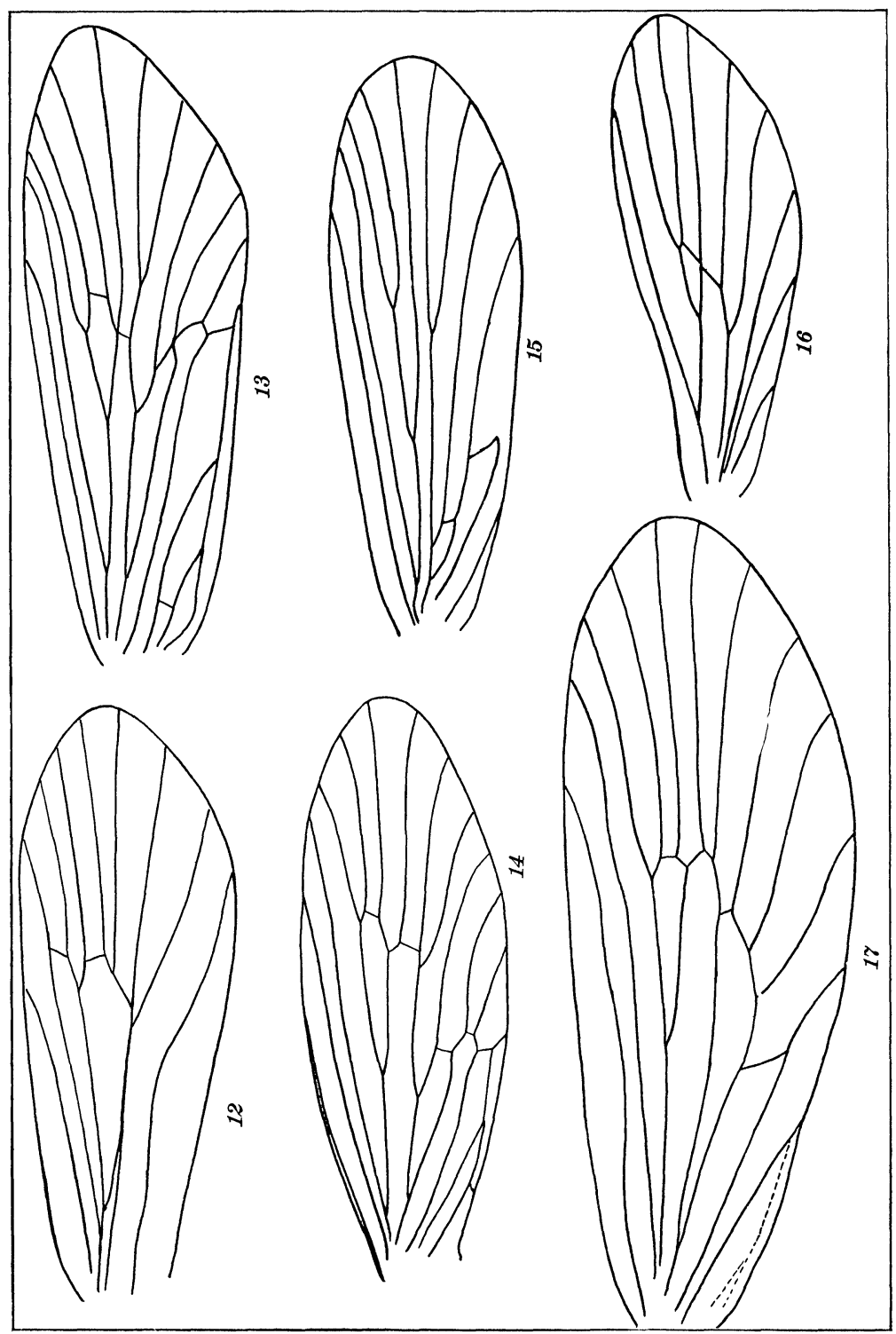

Carpenter-Trichoptera 

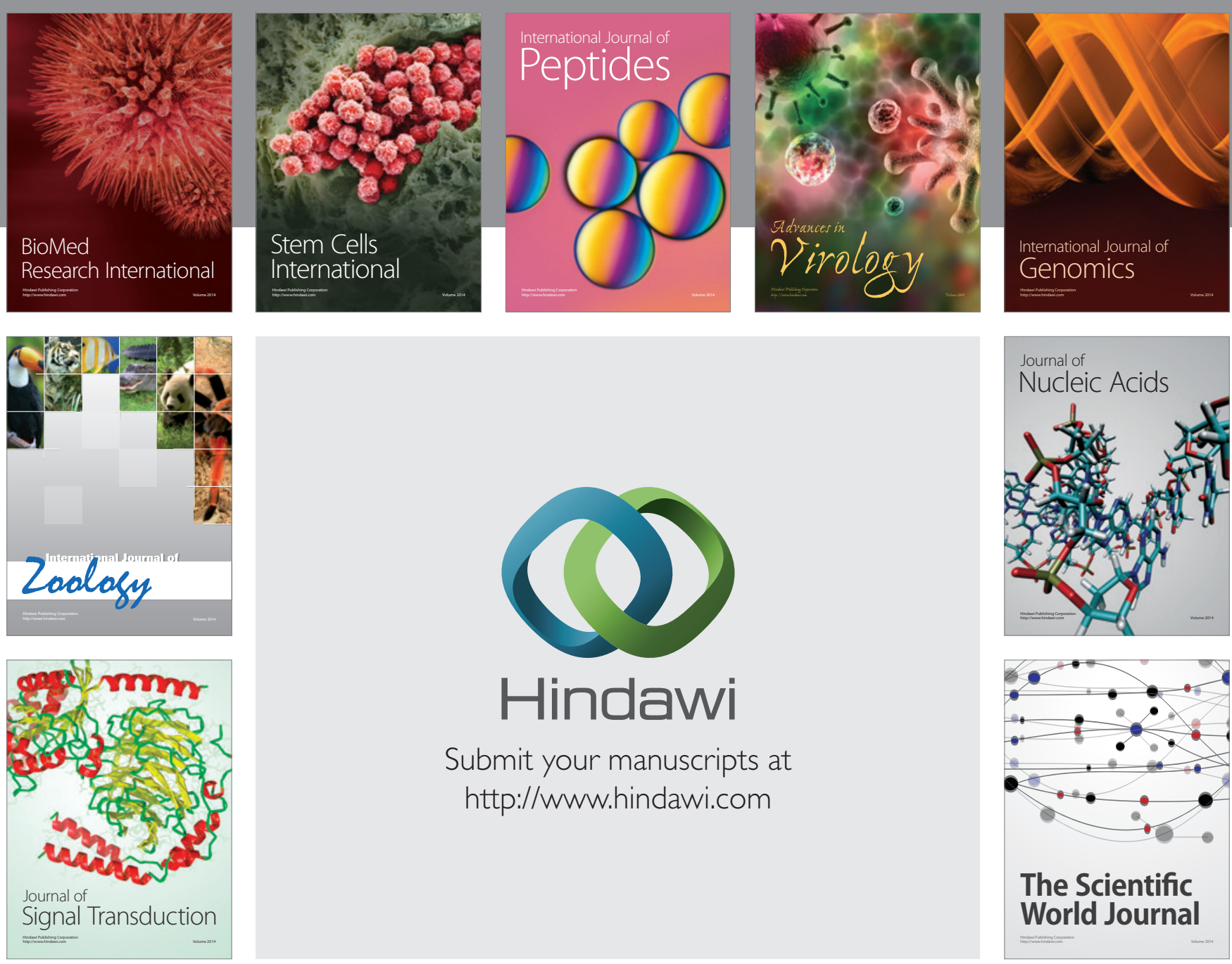

Submit your manuscripts at

http://www.hindawi.com
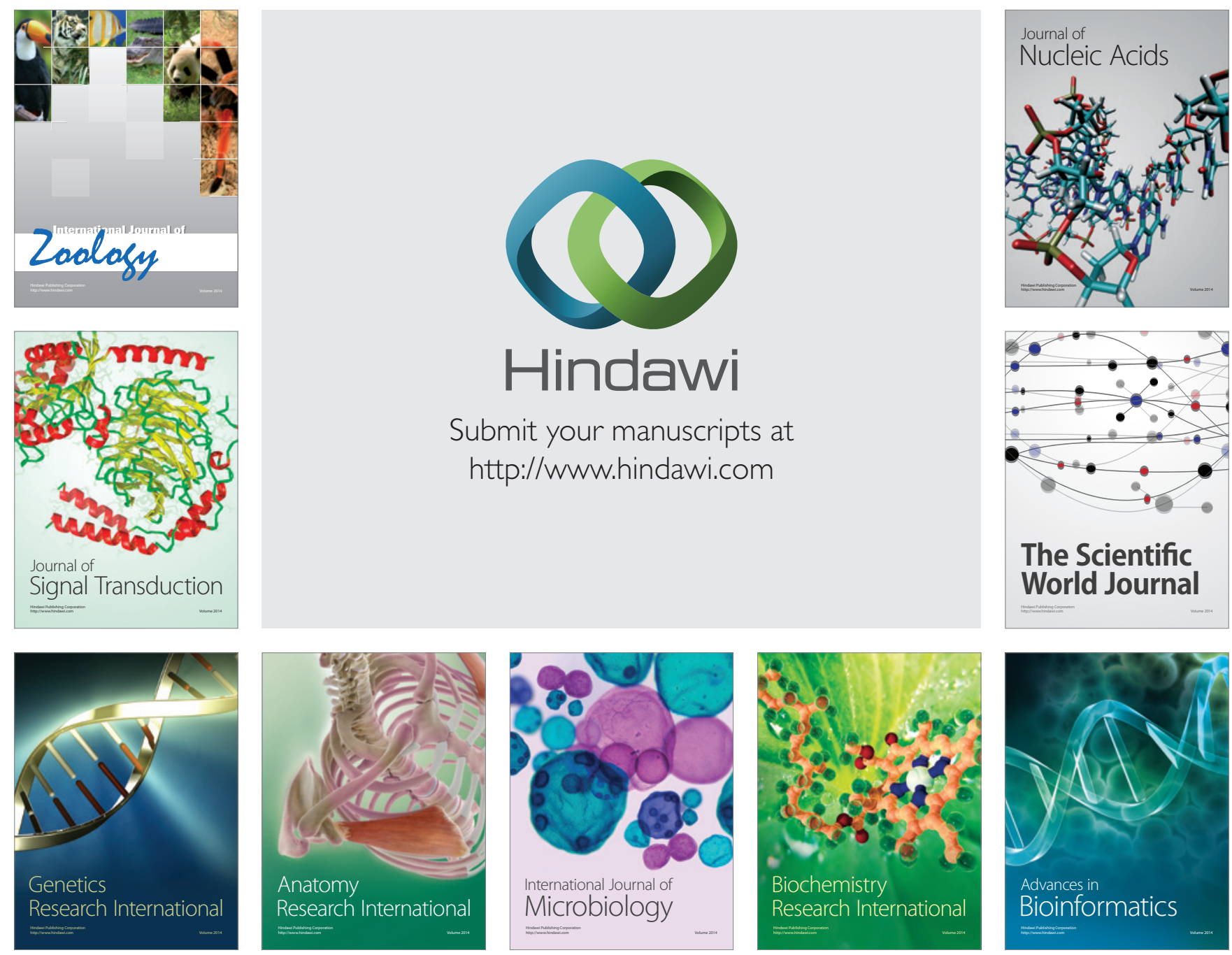

The Scientific World Journal
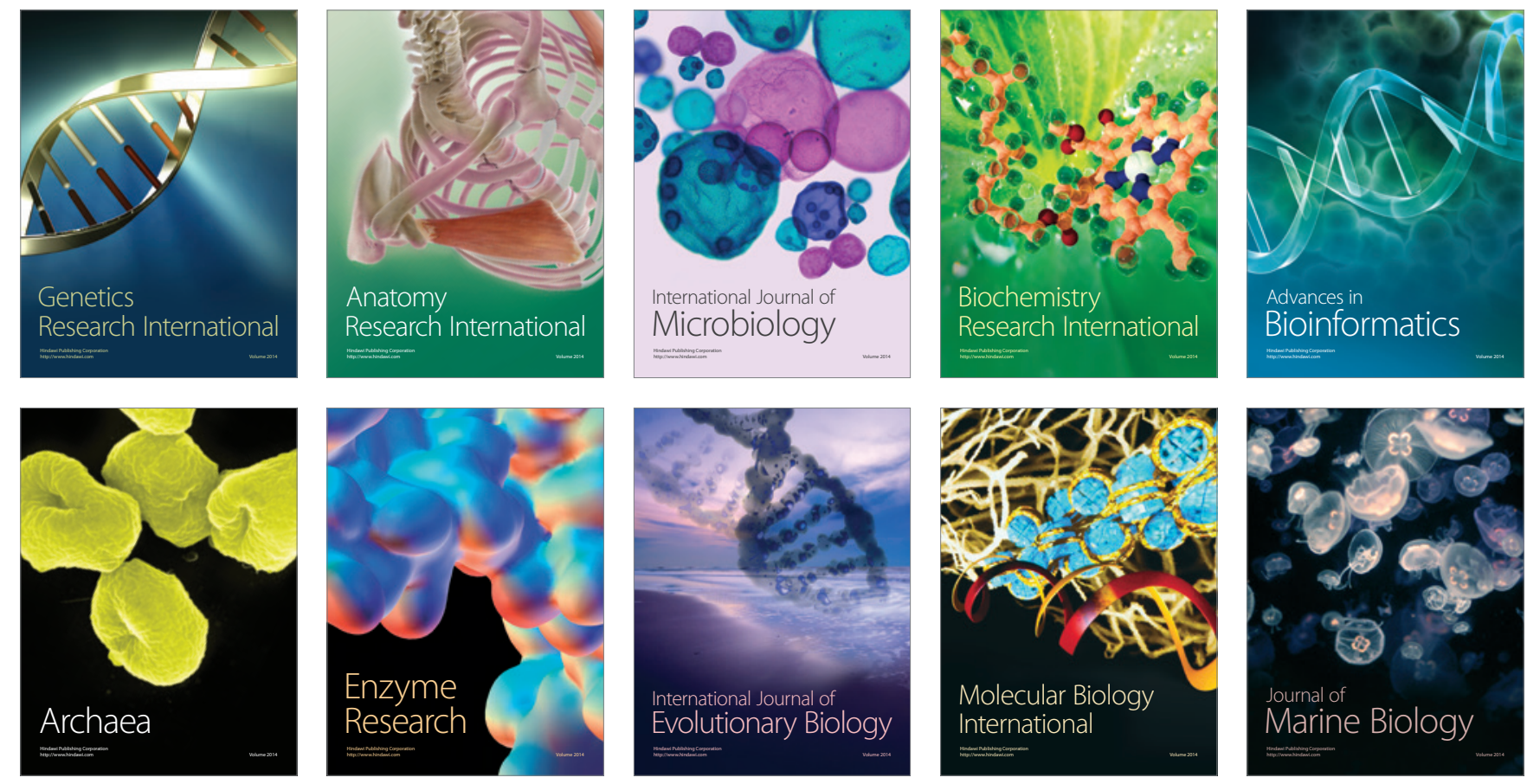